\title{
FUZZY LOGIC CONTROLLED SEPIC CONVERTER FOR MAXIMUM POWER TRACKING OF PHOTO VOLTAIC SYSTEMS
}

\author{
Priyanka M. Lale ${ }^{1}$, R. M. Nagarale ${ }^{2}$ \\ ${ }^{1}$ (Control System Engineering) Electronics Department, College of Engineering Ambajogai, Maharashtra, India. \\ ${ }^{2}$ (Instrumentation Department), College of Engineering Ambajogai, Maharashtra, India.
}

\begin{abstract}
In this paper, a modified $P \& O$ technique that uses fuzzy logic to control the amount of perturbation depending on operating point of PV solar cell is proposed. Fuzzy logic is used to achieve smooth adaptations in duty cycles as well as to control the rate of adaptation. Proposed method helps reducing steady state oscillations and increasing convergence speed. SEPIC (Single Ended Primary Inductor Converter) is employed to realize appropriate output from proposed MPPT control. The limitation of SEPIC to track dynamic variations is overcome by fast operation of control algorithm. The system is simulated and tested in MATLAB/Simulink.
\end{abstract}

Keywords-Maximum Power Point Tracking, Photovoltaic Systems, Fuzzy Logic, SEPIC Converter

\section{INTRODUCTION}

Rising concerns about reduction of fossil fuels and environmental aspects has promoted use of renewable energy sources for energy production. Wind, geothermal, tidal etc. are mainly beneficial on large scale at certain locations only; however the only source of energy which can be made available on variety of scales starting from few $\mathrm{kW}$ to several MWs as well as on convenient locations even like rooftops is the photovoltaic source utilizing solar power. It is highly recommended and required in developing countries like India, where more than enough solar power is available daily. There are certain technicalities involved however, the solar photovoltaic efficiency being very low as 15 to $20 \%$. Further, solar power is highly intermittent and it is not available in night. The prediction tools are not that accurate. Our duty is to extract maximum power out of whatever is available at a given point of time, which needs extensive use of power electronics. Maximum power has to be extracted in both variable solar input and variable load cases.

The problem of maximum power point tracking has extensively explored by researchers and several methods have been available for achieving MPPT. Common methods include perturb and observe $(\mathrm{P} \& \mathrm{O})$ [1]-[5], incremental conductance [6]-[9], optimization based methods [10], several bio-inspired techniques and other heuristic methods [11]-[16]. The most simple and fastest amongst all is P\&O. However, this method has a big limitation of continuous perturbation even in steady state, due to fixed amount of perturbation even if maximum power operation is achieved. Further, pre-fixed step at points far away from MPP aids to slower convergence. There are some methods using adaptive perturbation amount, however they do not make smooth variations in duty cycle or reference voltages as they use discrete set of values of reference points calculated from certain formula. When rate of change of power w.r.t. voltage of PV array is very high (e.g. sudden clouds, dynamic load variations and faults), such method fails to properly perturb. In order to have smooth control, fuzzy logic is found to be better [17]-[20]. Also, use of fuzzy look-up table (fuzzy curve in single-input, single-output case) greatly simplifies and speeds up the process. Some authors proposed fuzzy rule base taking error (proportional to difference between reference and actual voltage) and change in error as inputs. However in proposed method, only single input is used for fuzzy controller thereby reducing complexity and increasing decision speed. The input is taken as rate of change of power with respect to voltage of PV module/array, which is the indicator of distance of present operating point from the desired MPP.

The realization of achieving desired operating point of PV system is done through properly selected power electronic circuit, typically a dc-dc converter. Among several available converter types, SEPIC has more advantages such as noninverted output, more flexibility, availability of more inductance with less core, decoupling of input and output in spite of some limitations like complex fourth order system [21]- [23].

\section{PROPOSED SYSTEM}

The circuit diagram of considered PV system is shown in Fig. 1. SEPIC converter is fed from PV array, while its switching pulses are controlled from modified Fuzzy logic based adaptive perturb and observe MPPT algorithm. Output of SEPIC is fed to load, which is taken as of variable impedance type. The requirement of MPPT technique is to extract maximum power from PV array and deliver the same to load including losses, as quickly as possible. 


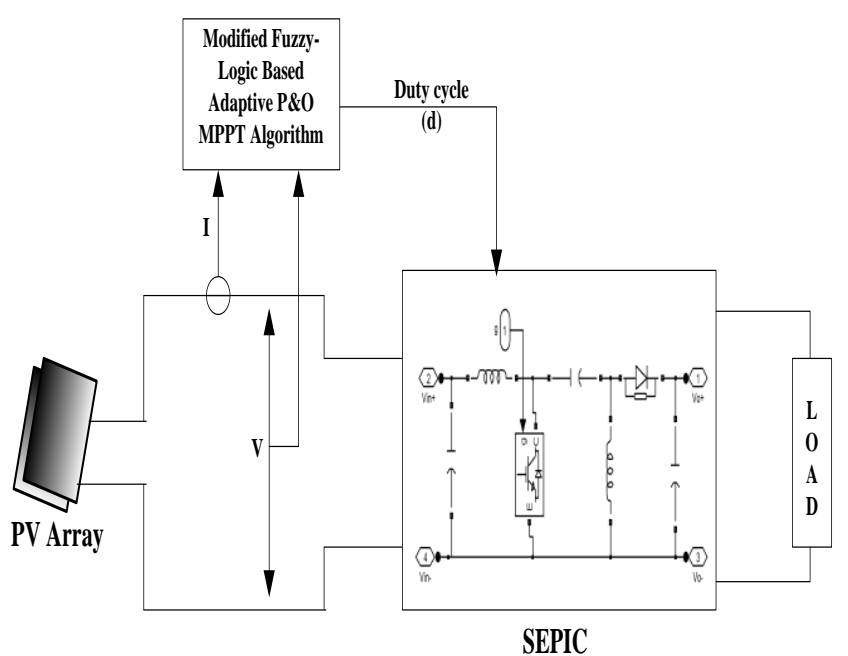

Fig. 1: System Diagram for Proposed MPPT by Fuzzy Controlled SEPIC

\subsection{PV Array}

Single diode equivalent circuit, as shown in Fig. 2, is generally used for simulation of one PV cell and the PV array is made up of series-parallel connection of such individual PV cells. The equations that define a PV cell are Eqn. (1), (2) and (3), the symbols and their meanings with their values are given in Table I. [24]

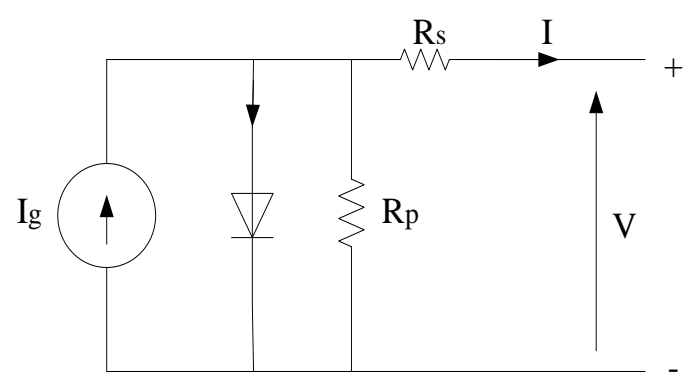

Fig. 2: Single diode equivalent circuit of a PV cell

$$
\begin{array}{r}
I=N_{p} I_{g}-N_{p} I_{o}\left[e^{\frac{q}{\eta k T}\left(\frac{V}{N_{s}}+\frac{I R_{s}}{N_{p}}\right)}-1\right] \\
-\frac{N_{p}}{R_{p}}\left(\frac{V}{N_{s}}+\frac{I_{s}}{N_{p}}\right) \\
I_{g}=\frac{S}{S_{\text {ref }}}\left[I_{g_{\text {ref }}}+C_{T}\left(T-T_{\text {ref }}\right)\right] \\
I_{o}=I_{o_{\text {ref }}}\left(\frac{T}{T_{\text {ref }}}\right)^{3} e^{\frac{q E_{g}}{\eta k}\left(\frac{1}{T_{\text {ref }}}-\frac{1}{T}\right)}
\end{array}
$$

Table 1: Symbols and Their Meanings

\begin{tabular}{ccc}
\hline Symbol & Meaning & Value \\
\hline $\mathrm{I}$ & PV array current & Variable \\
$\mathrm{V}$ & PV array voltage & Variable \\
$I_{g}$ & Photon generated current of a PV cell & Variable \\
$I_{\mathrm{g} \text { ref }}$ & Reference $I_{g}$ of a PV cell & $3.35 \mathrm{~A}$ \\
$I_{o}$ & Saturation current of diode & Variable \\
$I_{\mathrm{O} \text { ref }}$ & $I_{o}$ at reference conditions & $10^{-9} \mathrm{~A}$ \\
$\mathrm{~S}$ & Solar insolation in $W / \mathrm{m}^{2}$ & Variable \\
$S_{\text {ref }}$ & Reference solar insolation in $W / \mathrm{m}^{2}$ & $1000 \mathrm{~W} / \mathrm{m}^{2}$ \\
$\mathrm{~T}$ & Ambient temperature in Kelvin & Variable \\
$T_{\text {ref }}$ & Reference ambient temperature & $300 \mathrm{~K}$ \\
$\mathrm{q}$ & Charge of an electron in Coulombs & $1.602 \times 10^{-19}$ \\
$\eta$ & Diode ideality factor & 2 \\
$\mathrm{k}$ & Boltzman's constant $(\mathrm{J} / \mathrm{K})$ & $1.381 \times 10^{-23}$ \\
$E_{g}$ & Band gap energy of semiconductor & $1.237 \mathrm{eV}$ \\
$R_{s}$ & Series resistance of a PV cell & $0.312 \Omega$ \\
$R_{p}$ & Parallel resistance of a PV cell & $10^{4} \Omega$ \\
$N_{s}$ & Number of cells in series & 4 \\
$N_{p}$ & Number of cells in parallel & 5 \\
$C_{T}$ & Temperature coefficient & $0.065 \%$ \\
\hline
\end{tabular}

\subsection{SEPIC Converter}

Consider a SEPIC converter, if $\mathrm{V}_{\mathrm{o}}, \mathrm{I}_{\mathrm{o}}$ and $\mathrm{V}_{\text {in }}, \mathrm{I}_{\text {in }}$ are output and input voltages and currents respectively and $\mathrm{D}$ is the duty cycle, then Eqn. (4) approximately holds (assuming ideal devices),

$\mathrm{V}_{\mathrm{o}}=\frac{\mathrm{D}}{1-\mathrm{D}} \mathrm{V}_{\text {in }}$ and $\mathrm{I}_{\mathrm{o}}=\frac{1-\mathrm{D}}{\mathrm{D}} \mathrm{I}_{\text {in }}$

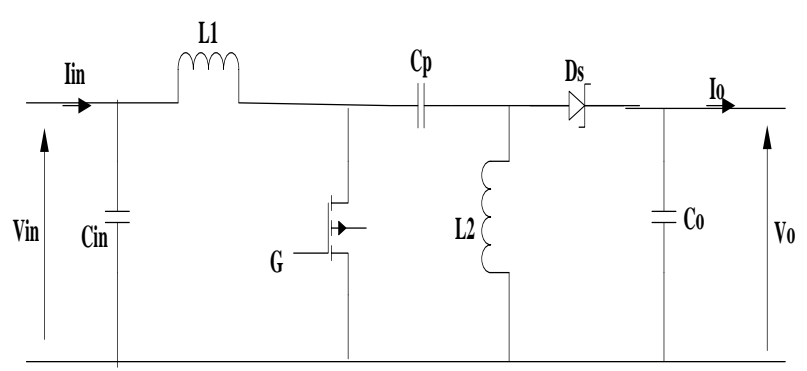

Fig. 3: SEPIC Converter

The load resistance Ro is reflected on input side of SEPIC as a different resistor of value dependent on duty ratio, as evident from Eqn. (5).

$$
\mathrm{R}_{\text {in }}=\frac{\mathrm{V}_{\text {in }}}{\mathrm{I}_{\text {in }}}=\left(\frac{1-\mathrm{D}}{\mathrm{D}}\right)^{2} \frac{\mathrm{V}_{\mathrm{o}}}{\mathrm{I}_{\mathrm{o}}}=\left(\frac{1-\mathrm{D}}{\mathrm{D}}\right)^{2} \mathrm{R}_{\mathrm{o}}
$$

It is clear from Eqn. (5) that input resistance seen by PV array can be controlled by varying $\mathrm{D}$, irrespective of any load resistance $R_{0}$. This provides a great flexibility of operation. It is important to vary input impedance of SEPIC since, at MPP, that must be equal to input impedance seen by PV array, as per maximum power transfer theorem. Eqn. (5) indicates an inverse relationship between $R_{\text {in }}$ and $D$.

For simulation, the values of elements in SEPIC are taken as, $\mathrm{C}_{\mathrm{in}}=2 \mathrm{mF}, \mathrm{L}_{1}=5 \mathrm{mH}, \mathrm{L}_{2}=1 \mathrm{mH}, \mathrm{C}_{\mathrm{p}}=470{ }^{0} \mathrm{~F}$ and $\mathrm{C}_{\mathrm{o}}=$ $5 \mathrm{mF}$. 


\subsection{Proposed MPPT Algorithm}

The slope of $\mathrm{P}-\mathrm{V}$ curve at point of maximum power is zero; it is positive on left side and negative on other side, as evident from Fig. 6 (b). Perturb and Observe method make use of this fact such that, duty cycle (D) is updated each time so as to achieve zero slope of $\mathrm{dP} / \mathrm{dV}$. Flow chart of conventional P\&O is shown in Fig. 4 (a).

In proposed method, the logic of MPP tracking is kept same as conventional $\mathrm{P} \& \mathrm{O}$, where each time the perturbation is made, the slope $\mathrm{dP} / \mathrm{dV}$ is checked and next perturbation is made in a direction to assist that slope towards zero. The difference in proposed method here is that, amount of perturbation in duty cycle is a variable and dependent on position of the operating point relative to MPP. If operating point is far away from MPP, it is obvious that fast and long perturbations are workable. As MPP is get closer, steps can be made smaller and smaller so as to attain fine and accurate position for steady state.

Fuzzy logic is used to generate a smooth curve establishing relationship between the slope $\mathrm{dP}=\mathrm{dV}$ and the step in duty ratio to be taken i.e. $\mathrm{dD}$. The fuzzy membership functions are defined (Table III) by seven groups for both input and output. The rule base (Table II) is defined considering principal of hill-climbing and inverse relation of duty ratio with voltage [Eqn. (4)].

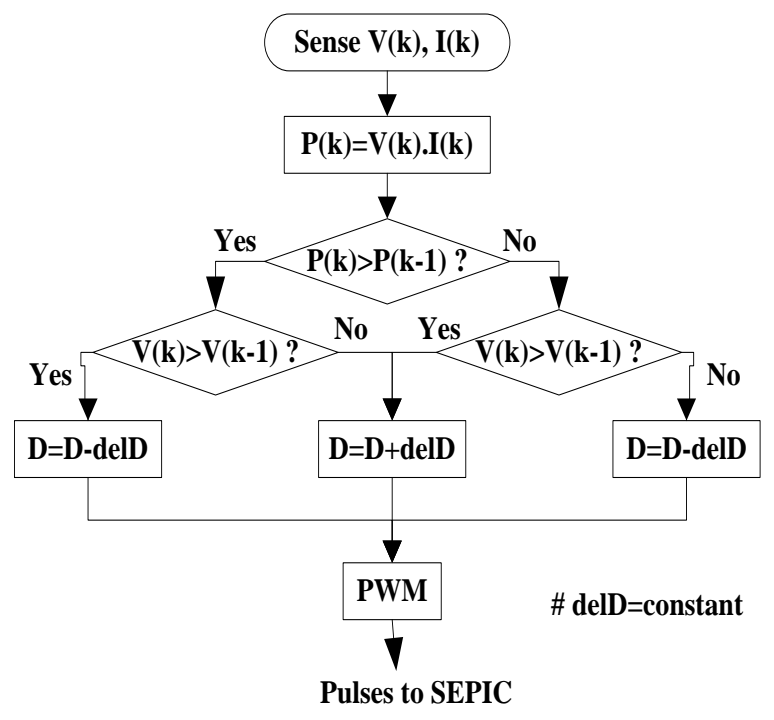

(a) Flow Chart of Conventional P\&O Method

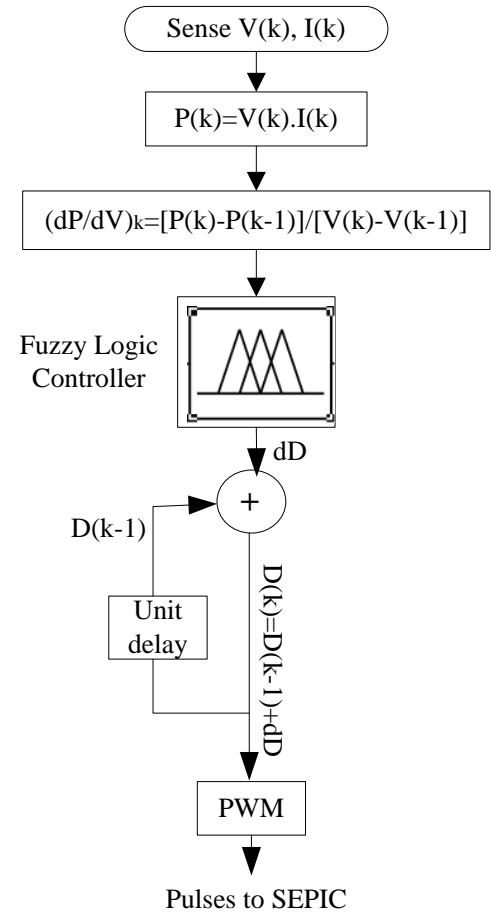

(b)

Flow Chart of Proposed Fuzzy Logic based Modified MPPT Algorithm

Fig. 4: Conventional Vs. Modified P\&O MPPT Methods

The flow chart of proposed algorithm, fuzzy membership functions and fuzzy look-up curve is depicted in Fig. 4 (b) and 5 respectively.

The membership functions have unequal shapes, the area assigned to part nearer to zero is gradually decreasing. This is to ensure the adaptive step-size to be taken at every hillclimbing step. Trapezoidal membership functions are chosen for values far away from zero since a big step with constant amplitude can be taken for such a vast range. Values for output $\mathrm{dD}$ i.e. change in duty cycle are chosen within range of $[-0.1,0.1]$, whereas that $\mathrm{dP} / \mathrm{dV}$ are chosen with high ranges (theoretically the range should be $(-\infty, \infty)$ ). The value of membership function at origin is zero indicating the operation at MPP itself.

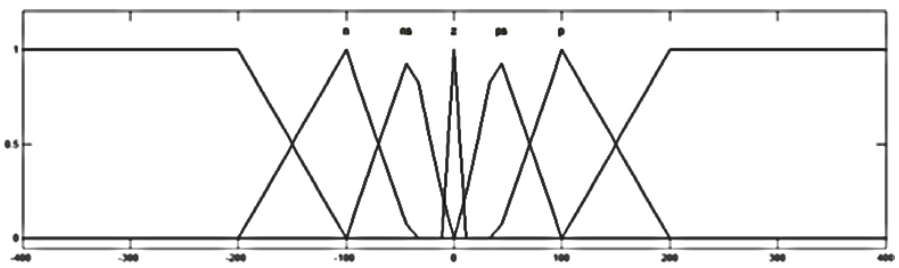

(a) Membership function of input $\mathrm{dP} / \mathrm{dV}$

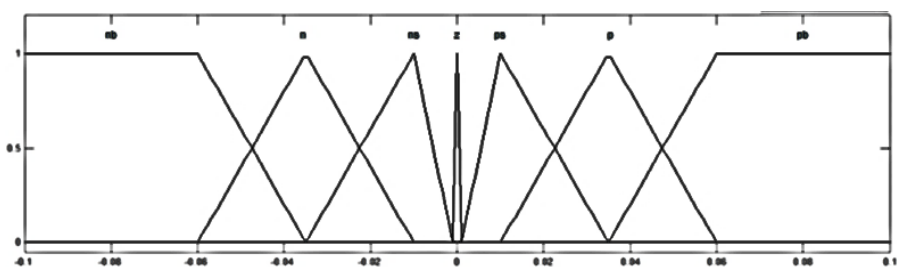

(b) Membership function of output $\mathrm{dD}$ 


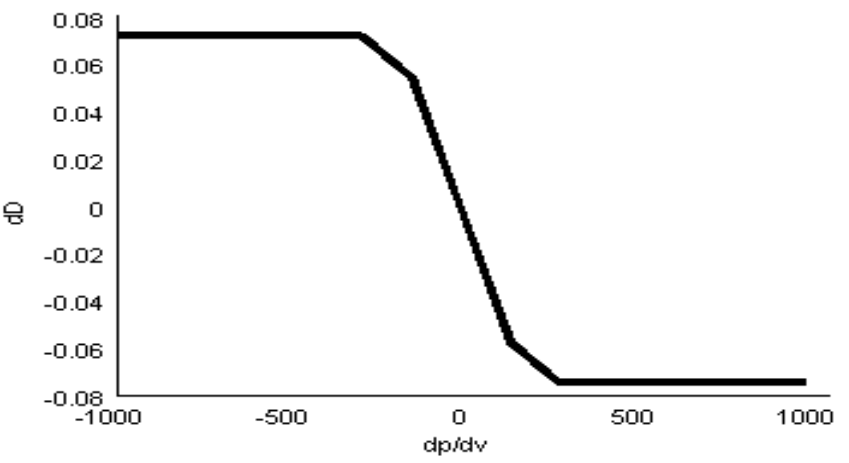

(c) Fuzzy Curve

Fig. 5: Membership Functions and their Relation

Table 2: Fuzzy Rule-Base

\begin{tabular}{|l|l|l|l|l|l|l|l|}
\hline If $\mathrm{dP} / \mathrm{dV}$ & $\mathrm{NB}$ & $\mathrm{N}$ & $\mathrm{NS}$ & $\mathrm{Z}$ & $\mathrm{PS}$ & $\mathrm{P}$ & $\mathrm{PB}$ \\
\hline Then $\mathrm{dD}$ & PB & P & PS & Z & NS & N & NB \\
\hline
\end{tabular}

Table 3: Membership Functions and Their Distribution

\begin{tabular}{|c|c|c|}
\hline & $d P / d V$ & dD \\
\hline NB & {$\left[\begin{array}{cccc}-20000 & -20000 & -200 & -100\end{array}\right]$} & {$\left[\begin{array}{llll}-0.1 & -0.1 & -0.06 & -0.035\end{array}\right]$} \\
\hline $\mathbf{N}$ & {$\left[\begin{array}{llll}-200 & -100 & -40\end{array}\right]$} & {$[-0.06-0.035-0.01]$} \\
\hline NS & {$\left[\begin{array}{lll}-100 & -40 & -2\end{array}\right]$} & {$\left[\begin{array}{lll}-0.035 & -0.01 & -0.001]\end{array}\right]$} \\
\hline $\mathbf{Z}$ & {$\left[\begin{array}{lll}-10 & 0 & 10\end{array}\right]$} & {$\left[\begin{array}{lll}-0.001 & 0 & 0.001\end{array}\right]$} \\
\hline PS & {$\left[\begin{array}{lll}2 & 40 & 100\end{array}\right]$} & {$\left[\begin{array}{lll}0.001 & 0.01 & 0.035\end{array}\right]$} \\
\hline $\mathbf{P}$ & {$\left[\begin{array}{lll}40 & 100 & 200\end{array}\right]$} & {$\left[\begin{array}{lll}0.01 & 0.035 & 0.06\end{array}\right]$} \\
\hline PB & {$\left[\begin{array}{llll}100 & 200 & 20000 & 20000\end{array}\right]$} & {$\left[\begin{array}{lllll}0.035 & 0.06 & 0.1 & 0.1\end{array}\right]$} \\
\hline
\end{tabular}

\section{SIMULATION RESULTS AND DISCUSSIONS}

The I-V and P-V characteristics of simulated photovoltaic array are shown in Fig. 6 for various temperatures and solar insolation values. It can be observed that, under standard test conditions with $\mathrm{S}=1000 \mathrm{~W} / \mathrm{m}^{2}$ and $\mathrm{T}=300 \mathrm{~K}$, the maximum power of $\mathrm{P}_{\max }=2100 \mathrm{~W}$ is achieved at a voltage of around $\mathrm{V}_{\mathrm{m}}=132 \mathrm{~V}$. Also, impact of temperature variation on operating characteristics of PV array is not much as compared to impact of solar insolation variation. In practice, ambient temperature does not vary so much, whereas solar insolation greatly fluctuates as per climatic conditions, clouds and other distractions causing shadows.

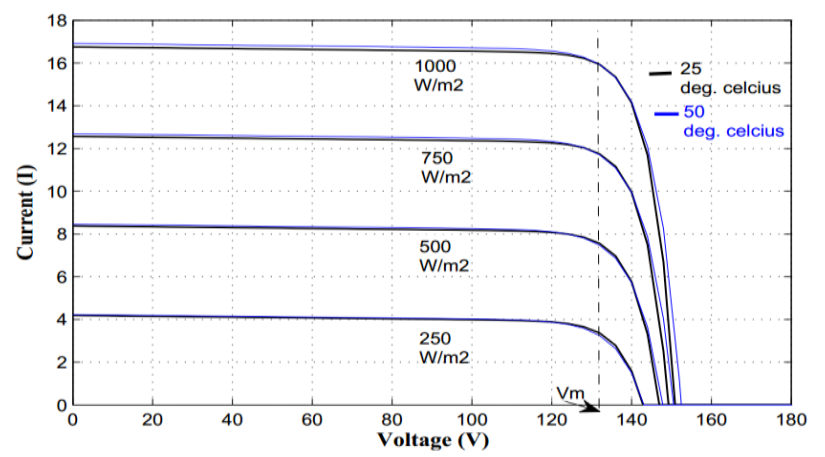

(a) I-V Characteristics

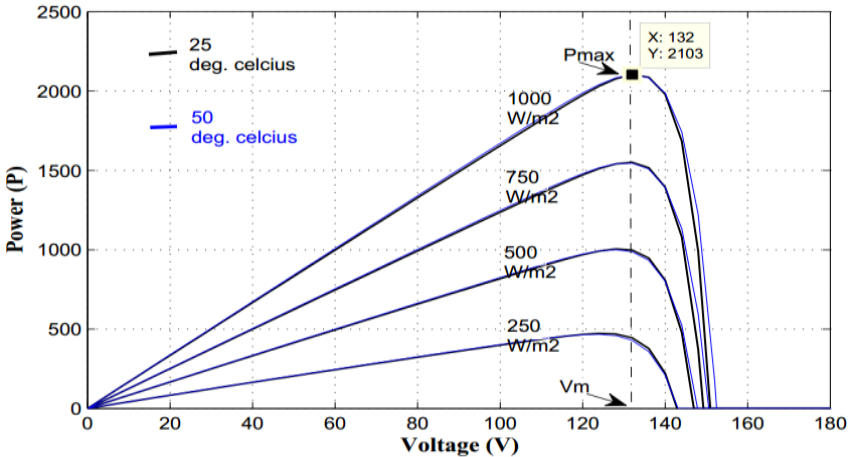

(b) P-V Characteristics

Fig. 6: Characteristics of Simulated PV Module

The system of Fig. 1 is simulated with $\mathrm{S}=500 \mathrm{~W} / \mathrm{m}^{2}$ and T $=300 \mathrm{~K}$. The results of input and output powers are compared with conventional $\mathrm{P} \& \mathrm{O}$ algorithm. The maximum power of Pmax $=1000 \mathrm{~W}$ (refer Fig. 6 (b)) is effectively tracked by proposed method within less time and with least oscillations in steady state output.

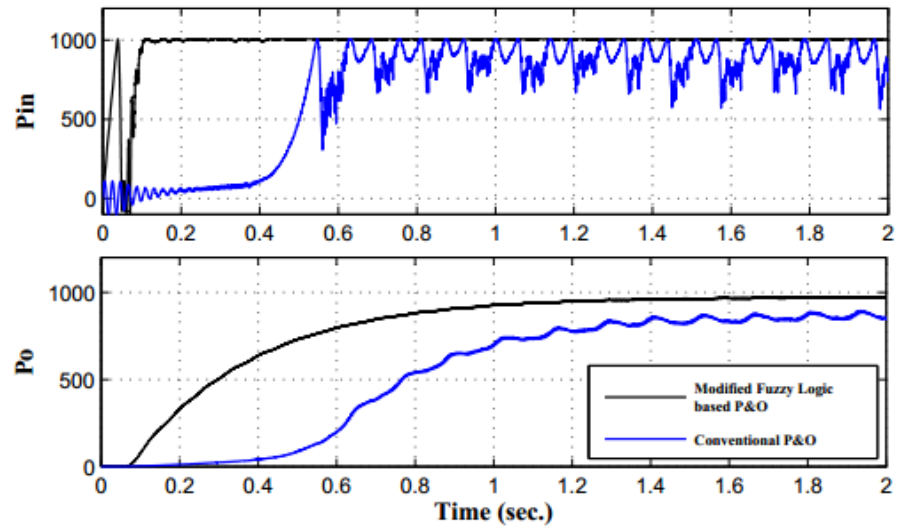

Fig. 7: Comparison of Proposed MPPT Method with Conventional Fixed Perturbation P\&O
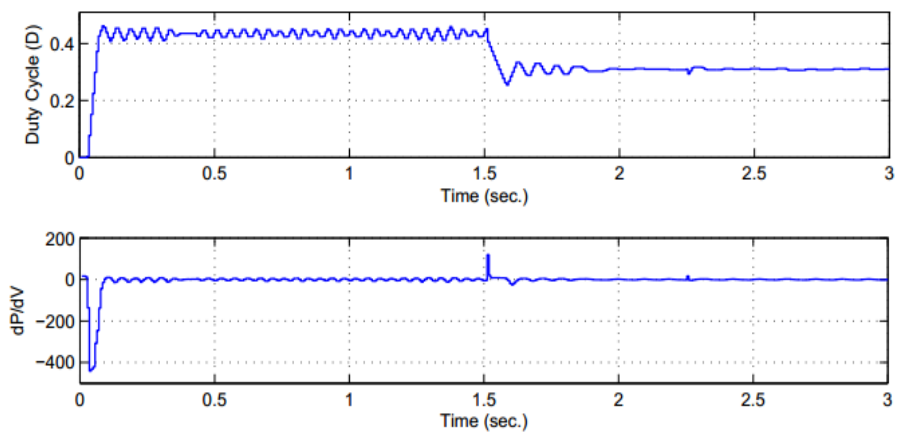

(a) Input and Output of Fuzzy Logic Controller 

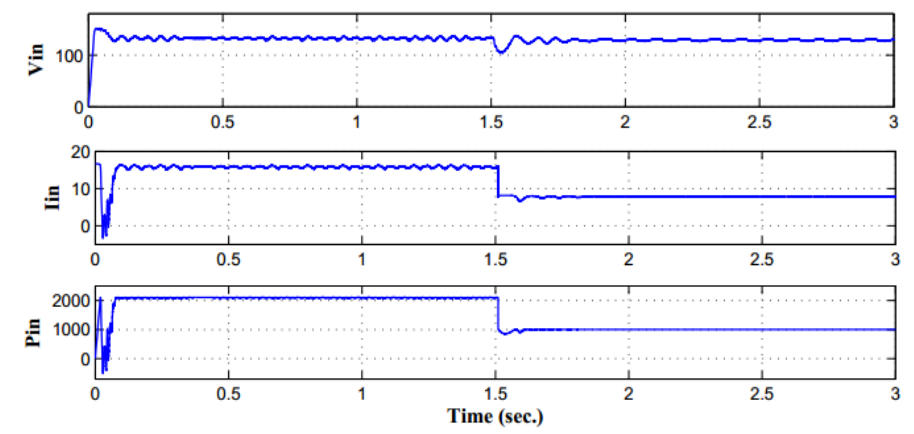

(b) Input of SEPIC
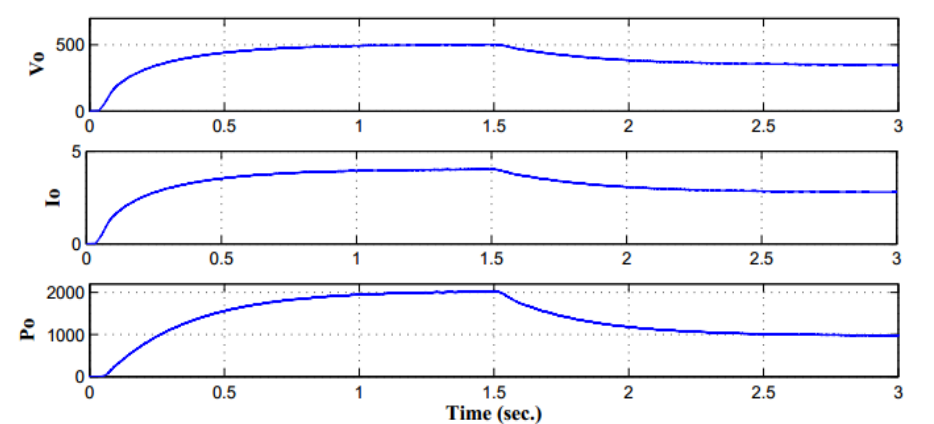

(c) Output of SEPIC

Fig. 8: Performance of Proposed MPPT Method

To validate the performance of proposed method with dynamic variations on environmental side as well as electrical load side, two disturbances are created. One at 1.5 sec., where solar insolation suddenly reduces from 1000 $\mathrm{W}=\mathrm{m}^{2}$ to $500 \mathrm{~W}=\mathrm{m}^{2}$. Secondly, at 2.25 sec., electrical load is varied from 5 to 50 . The simulation results are shown in Fig. 8.

It can be observed that, solar irradiation has great impact on output power since $\mathrm{P}-\mathrm{V}$ characteristics is completely changed. The algorithm quickly senses this change and varies its duty ratio to desired value where a new maximum power is tracked.

The oscillations in duty cycle die out after few milliseconds, so those in the input and output voltages and currents. The input power to SEPIC is almost instantaneously changed. Output power varies slowly due to time delay caused by SEPIC converter.

Load resistance variation has little impact, since very little change in duty ratio is needed and same maximum power point is continuing. Also, change in the slope i.e. $\mathrm{dP} / \mathrm{dV}$ is very negligible. It can be noted that, maximum power point is characteristics of PV array and not that of load. In this case, duty ratio is changed to ensure impedance matching as per maximum power transfer theorem.

The method seems to work robust under drifting phenomenon. When P-V characteristics are dynamically changing, there is possibility in conventional $\mathrm{P} \& \mathrm{O}$ method to track in wrong direction since $\mathrm{dP} / \mathrm{dV}$ may have wrong sign in a direction. However, in proposed method, both left and right sides of MPP are not equally climbed. The left side having comparatively little absolute slope w.r.t. right side of MPP, is climbed slower. If drifting causes MPP to shift towards right, method will see a negative slope $\mathrm{dP} / \mathrm{dV}$ and speedily go away the MPP. Thus, phenomenon can be quickly recovered once the new characteristics become steady. Here, drifting cannot be avoided however it can be suffered through very quickly by the proposed method.

\section{CONCLUSION}

A new MPPT method for photovoltaic systems is proposed. Fuzzy logic based controller is used to optimally adapt step size and perturbation amount in the conventional $\mathrm{P} \& \mathrm{O}$ method. SEPIC converter is used to realize the control method. The proposed method seems to achieve fastness and steady-state accuracy compared to conventional method. Proposed technique is simple to implement and will be implemented in future in the form of real-time hardware.

\section{REFERENCES}

[1] A. K. Abdelsalam, A. M. Massoud, S. Ahmed, and P. N. Enjeti, "High performance adaptive perturb and observe mppt technique for photovoltaic-based microgrids," IEEE Transactions on Power Electronics, vol. 26, no. 4, pp. 1010-1021, 2011.

[2] N. Femia, G. Petrone, G. Spagnuolo, and M. Vitelli, "Optimization of perturb and observe maximum power point tracking method," IEEE transactions on power electronics, vol. 20, no. 4, pp. 963-973, 2005.

[3] N. Femia, D. Granozio, G. Petrone, G. Spagnuolo, and M. Vitelli, "Predictive \& adaptive mppt perturb and observe method," IEEE Trans- actions on Aerospace and Electronic Systems, vol. 43, no. 3, pp. 934- 950, 2007.

[4] N. Femia, G. Petrone, G. Spagnuolo, and M. Vitelli, "Perturb and observe mppt technique robustness improved," in Industrial Electronics, 2004 IEEE International Symposium on, vol. 2, 2004, pp. 845-850.

[5] Y. Yang and F. P. Zhao, "Adaptive perturb and observe mppt tech- nique for grid-connected photovoltaic inverters," Procedia Engineering, vol. 23, pp. 468-473, 2011.

[6] D. Sera, L. Mathe, T. Kerekes, S. V. Spataru, and R. Teodorescu, "On the perturb-and-observe and incremental conductance mppt methods for pv systems," IEEE journal of photovoltaics, vol. 3, no. 3, pp. 1070-1078, 2013.

[7] A. Safari and S. Mekhilef, "Simulation and hardware implementation of incremental conductance mppt with direct control method using cuk converter," IEEE Transactions on Industrial Electronics, vol. 58, no. 4, pp. 1154-1161, 2011.

[8] K. S. Tey and S. Mekhilef, "Modified incremental conductance mppt algorithm to mitigate inaccurate responses under fast-changing solar irradiation level," Solar Energy, vol. 101, pp. 333-342, 2014.

[9] Q. Mei, M. Shan, L. Liu, and J. M. Guerrero, "A novel improved variable step-size incremental-resistance 
mppt method for pv systems," IEEE Transactions on Industrial Electronics, vol. 58, no. 6, pp. 2427-2434, 2011.

[10] A. Askarzadeh, "Optimisation of solar and wind energy systems: a survey," International Journal of Ambient Energy, pp. 1-10, 2016.

[11] A. Oshaba, E. Ali, and S. Abd Elazim, "Pi controller design using artificial bee colony algorithm for mppt of photovoltaic system supplied dc motor-pump load," Complexity, 2015.

[12] A. Oshaba, E. Ali, and S. A. Elazim, "Mppt control design of pv system supplied srm using bat search algorithm," Sustainable Energy, Grids and Networks, vol. 2, pp. 51-60, 2015.

[13] T. Manmadharao, P. Balamurali, and C. Ravikumar, "Maximum power point tracking of a pv system by bacteria foraging oriented particle swarm optimization."

[14] S. E. De Le ón-Aldaco, H. Calleja and J. A. Alquicira, "Metaheuristic optimization methods applied to power converters: A review," IEEE Transactions on Power Electronics, vol. 30, no. 12, pp. 6791-6803, 2015.

[15] K. Ishaque, Z. Salam, M. Amjad, and S. Mekhilef, “An improved particle swarm optimization (pso)-based mppt for pv with reduced steady-state oscillation," IEEE transactions on Power Electronics, vol. 27, no. 8, pp. 3627-3638, 2012.

[16] A. A. Kulaksiz and R. Akkaya, "A genetic algorithm optimized ann- based mppt algorithm for a stand-alone pv system with induction motor drive," Solar Energy, vol. 86, no. 9, pp. 2366-2375, 2012.

[17] A. El Khateb, N. A. Rahim, J. Selvaraj, and M. N. Uddin, "Fuzzy-logic- controller-based sepic converter for maximum power point tracking," IEEE Transactions on Industry Applications, vol. 50, no. 4, pp. 2349-2358, 2014.

[18] A. Al Nabulsi and R. Dhaouadi, "Efficiency optimization of a dsp-based standalone pv system using fuzzy logic and dual-mppt control," IEEE Transactions on Industrial Informatics, vol. 8, no. 3, pp. 573-584, 2012.

[19] B. N. Alajmi, K. H. Ahmed, S. J. Finney, and B. W. Williams, "Fuzzy-logic-control approach of a modified hill-climbing method for maximum power point in microgrid standalone photovoltaic system," IEEE Transactions on Power Electronics, vol. 26, no. 4, pp. 1022-1030, 2011.

[20] H. Bounechba, A. Bouzid, K. Nabti, and H. Benalla, "Comparison of perturb \& observe and fuzzy logic in maximum power point tracker for PV systems," Energy Procedia, vol. 50, pp. 677-684, 2014.

[21] S. Chiang, H.-J. Shieh, and M.-C. Chen, "Modeling and control of PV charger system with sepic converter," IEEE Transactions on Industrial Electronics, vol. 56, no. 11, pp. 4344-4353, 2009.

[22] M. Veerachary, "Power tracking for nonlinear pv sources with coupled inductor sepic converter," IEEE transactions on aerospace and electronic systems, vol. 41, no. 3, pp. 1019-1029, 2005.

[23] E. Mamarelis, G. Petrone, and G. Spagnuolo, "Design of a sliding- mode-controlled sepic for $\mathrm{pv}$ mppt applications," IEEE Transactions on Industrial Electronics, vol. 61, no. 7, pp. 3387-3398, 2014.

[24] F. Ding, P. Li, B. Huang, F. Gao, C. Ding, and C. Wang, "Modeling and simulation of grid-connected hybrid photovoltaic/battery distributed generation system," in CICED 2010 Proceedings. IEEE, 2010, pp. $1-10$. 